\title{
Impact of Irrigation Method on Root Rot and Wilt Diseases in Tomato Under Net Greenhouse in The State of Qatar.
}

\author{
Masoud.J. Al-marri', Osman A. Elsharief Abdalla ${ }^{1}$, Sheeja Thomas, ${ }^{1}$ Mohammed Al-Masri', Mohammed I. \\ Abubaker ${ }^{1}$, Mohamed $\mathrm{M}^{2}$, Hichem $\mathrm{R}^{3}$, Mohamed. M.Mazen. ${ }^{1}$ \\ ${ }^{1}$ Department of Agricultural Research, Ministry of Municipality \& Environment Doha, Qatar \\ 1mmmetwally@mme.gov.qa,mjmmarri@mme.gov.qa \\ ²Eremology and Combating Desertification Lab., Institut des Regions Arides (IRA), Tunise. \\ ${ }^{3}$ Institut Superieur Agronmique Chott Meriem, Sousse, Tunisie
}

\begin{abstract}
The study involved the relationship among two irrigation methods; Subsurface Buried Diffuser (SBD) and Conventional Drip irrigation (DI) and their impact on the survival of healthy tomato plant. Tomato plant irrigated with SBD and DI methods were subjected to survey of root or shoot systems fungal diseases and infected vs. healthy Tomato plant survival incidence percentage were recorded. Surveyed tomato plant showing, root rot and wilt symptoms were subjected to isolation trails for the purpose of isolation of the causal organisms. Rhizospheric samples of different healthy and diseased plants were collected at flowering growth stage for determining the frequency occurrence of different fungi associated with the root region of healthy and infected roots of tomato plants under both irrigation methods. It was observed that the Tomato plants irrigated under DI method were more prone to fungal infection than that of SBD method. Pathogenic fungi that contributed in reducing the survival of tomato plant were high in rhizospheric soil irrigated with DI irrigation Method as compared to SBD irrigation method. The root fungal pathogens isolated from rhizospheric soil were Fusarium solani, Fusarium oxysporum, Aspergillus spp., and Pythium spp., which recorded in high frequency comparing with other microorganisms. The genus Fusarium represented in highest records followed by the genus Rhizoctonia and Pythium respectively at all assayed samples.
\end{abstract}

Keywords: Root rot and wilt; Fusarium solani and Fusarium oxysporum; drip versus buried diffuser; netgreenhouse tomato; salt accumulation.

Language: English

Date of Publication: 2018-25-10

ISSN: 2349-0837

Volume: 08 Issue: 01

Journal: Journal of Advances in Agriculture

Website: https://cirworld.com

This work is licensed under a Creative Commons Attribution 4.0 International License.

How to Cite: Mazen, M., Al-marri, M., Abdalla, O. A., Thomas, S., Al-Masri, M., I. Abubaker, M., M., M., \& R., H. (2018). Impact of Irrigation method on root rot and wilt diseases in Tomato under net greenhouse in the State of Qatar. JOURNAL OF ADVANCES IN AGRICULTURE, 8(1), 1452-1466. https://doi.org/10.24297/jaa.v8i1.7771 


\section{INTRODUCTION}

Soil microorganisms play vital roles in the soil ecosystem, dominating the cycling of nutrients, the decomposition of organic matter and the maintenance of soil fertility(Wang et al., 2008). Microorganisms respond rapidly to the changes in their environment and following disturbance, changes in soil condition are expected to affect the activity, structure and function of the microbial community. Because of microbial sensitivity, biological properties of soil have been proposed as early and sensitivity indicators of soil ecological stress or other environment change (Jiang et al., 2012). The total microbial abundance is a basic indicator of soil quality. Soil structure and fertility loss are one of the main causes of soil degradation. They are also considered as a major threat to crop production and food security for future generations.

The use of inappropriate irrigation practices could result in a degradation of soil quality and can increase pathogenic microbial flora in the soil. The diseases that are caused by pathogens which persist (survive) in the soil matrix and in residues on the soil surface are defined as soil-borne diseases. Thus, the soil is a reservoir of inoculum of these pathogens, the majority of which are widely distributed in agricultural soils.

However, some species show localized distribution patterns. Most often damage to root and crown tissues of the plant is hidden in the soil. Thus, these diseases may not be noticed until the above-ground (foliar) parts of the plant are affected severely showing symptoms such as stunting, wilting, chlorosis and death(Veena et al., 2014).

Agricultural development activities in Qatar focus on developing modern irrigation systems, improving food quality, introducing modern technologies such as protected and intensive farming, diversifying cropping patterns and enhancing guidance, organizational and monitoring mechanisms. The tropic dry and hot weather existing in Qatar leads to a climatic water - balance deficit situation. The lack of rainfall recharge to groundwater or surface water consequently lead to water scarcity in one hand which when coupled with high rates of groundwater withdrawal for the agricultural consumption makes the country experiences an extremely high level of water stress. To ensure the efficient use of water, surface drip or subsurface irrigation systems are among the well-recognized modern water saving technologies used for irrigation. In drip irrigation water is provided either above surface drip irrigation or directly into the zoot zone known as subsurface drip irrigation (SDI) (Kirda et al., 2005; Wang et al.,2009). The mesh covered greenhouse tomato cultivation in Qatar has also been depending on surface drip irrigation for plant watering.

The long-term irrigation with surface drip irrigation method resulted in the accumulation of salt on the surface and this can lead to the soil-borne disease of tomato plant with an increased yield of the infected plant. Many factors in the soil influence the activity of soilborne pathogens and diseases: soil type, texture, $\mathrm{pH}$, moisture, temperature, salt accumulation and nutrient levels are among them. Accumulation of salt on the soil surface reduces the drainage property of soil. Soils that drain poorly, however, tend to favor the survival and distribution of soil-borne pathogens such as Pythium, Phytophthora, and Aphanomyces. Similarly, Fusarium and Verticillium wilts can also be more severe in wet soils than the dry soil (Veena et al., 2014).

The deposition of salt on the surface of the soil can increase the presence of pathogenic fungi in the soil. The composition of the microbial community may be affected by salinity since the microbial genotypes differ in their tolerance of a low osmotic (Chowdhury et al., 2011). In fungi, a low osmotic potential decreases spore germination and the growth of hyphae and changes the morphology and gene expression resulting in the formation of spores with thick walls (Juniper and Abbott, 2006). Fungi have been reported to be more sensitive to osmotic stress than bacteria (Sardinha et al., 2003; Wichern et al., 2006). The elevated salinity weakens plants due to the increase in osmotic pressure and toxic effects of salt. There is a significant reduction in the total fungal count in soils solemnized with different concentrations of sodium chloride (Elisabeth Francisconic Fay., 2016).

In Drip Irrigation Method water accumulation on the surface can also promote the growth of algae and causes an increase in the growth of the weeds. Chances of evaporation of accumulated water also increase as Qatar 
witnesses high temperature, which leads to the water loss in the region of Qatar. Chances of soil erosion and run off fertilizer into the groundwater are also there. All these factors will directly affect the yield of the growing vegetables and lead to the loss of production. To overcome all the limitation caused by using the drip surface irrigation system, a new and latest system called Buried diffuser subsurface irrigation method was employed. This irrigation system developed in Tunisia (Chahbani., 2012) is a proven innovation which received several international awards and may provide an improvement in terms of better water use efficiency compared to the current countrywide used surface drip irrigation system. Buried diffuser irrigation method involves irrigating only the part of the root zone permitting the other part to be dry. Water is used at the maximum level as water was supplied directly to the root of the plant. Water loss by evaporation is less as compared to the surface dripped irrigation method. No water is available for the weeds and algae growth. Chances of soil erosion are less. Soil infiltration capacity is increased. Fertilizers and groundwater are not mixed. Seed germination is improved and at the same time can use recycled water safely. The salinity of the soil decreased with buried dripper irrigation method which promotes the growth of the healthy tomato plant as compared to the surface drip irrigation method. The high frequency of irrigation with Buried Diffuser allows maintenance of optimum soil moisture content in the root zone. The partial soil wetting provided by Buried diffuser irrigation method has several benefits as it improves the efficiency of nutrient uptake at the fringes of the wetted soil volume. Applying water through Buried diffuser irrigation method maintains dry crop foliage and its benefits include reduced incidence of wilt and root rot plant disease. Buried diffuser irrigation method maintains soil surface structure more effectively than other irrigation types and makes it easier to allow for rainfall events or 'catch up', provided there is sufficient system capacity. A well maintained Buried diffuser irrigation method system requires less labor to operate than the alternative systems.

The aim of the present work was designed to monitor, diseases incidence caused by some fungi, to perform the microbial count of associated rhizospheric microorganisms and to monitor the frequency occurrence of pathogenic fungi causing wilt and root rot which can be used to compare the survival of the healthy plant under the two irrigation methods which are the conventional surface drip (DI) and the subsurface buried diffuser method (SBD) on the tomato cultivation in a net greenhouse in Qatar.

\section{MATERIAL \& METHODS}

\subsection{Study site overview}

The experiment was located in Al Utouriya Agricultural Research Farm (25 $\left.13^{\prime} 18^{\prime \prime} \mathrm{N} 51^{\circ} 28^{\prime} 58^{\prime \prime} \mathrm{E}\right)$ of the Department of Agricultural Research, Ministry of Municipality \& Environment. The country is situated in the Arabian Peninsula within the Arabian Gulf. A field experiment was conducted during the winter season extending over the years 2016/2017 and 2017/2018. The soil mixture of the planting bed of the net greenhouses which was used for the experiment was sandy loam to sandy clay loam soil with low organic matter content (0.37-1.4\%), moderate $\mathrm{pH}$ (7.41-8.14 and high calcium carbonate (24.16-39.4\%). The measurements for the $30 \mathrm{~cm}$ deep soil in a volumetric percentage unit of the field capacity were in the range of 11.28-18.49. The soil salinity, expressed in terms of electrical conductivity (ECe) values, measured one month after transplanting of the crop in the net greenhouse, were in the range of $2.23-3.26 \mathrm{dS} / \mathrm{m}$. In this experiment, two drip irrigation methods were applied: Conventional Drip (DI) and the newly introduced buried diffuser (SBD), each at three irrigation levels viz: $100 \%, 75 \%$ and $50 \%$ of the crop water consumption. The SBD method used a network composed of plastic diffusers which are connected each to a $2 \mathrm{~mm}$-diameter tube connected to a standard regulating dripper to provide with a stable water flow to the diffuser. The $2 \mathrm{~mm}$ tubes were linked to an above-ground sub-pipe of $13 \mathrm{~mm}$-diameter used as the main water supplying source within each net greenhouse. The sub-pipe was branching from the main $50 \mathrm{~mm}$ pipe which was connected in its turn to an elevated tank (300-gallon capacity, $1 \mathrm{~m}$ above ground surface). No water pumping was needed. Irrigation water from the tank was passing irrigation water through a water meter giving out readings for each one irrigation event. When water is turned on, the diffusers become filled with water. The buried diffuser installation was made ready by pre-digging one hole in the planting row, a diffuser is buried in each hole at a depth of about $10 \mathrm{~cm}$. The transplanting was manually implemented The DI method was performed with the 
same three irrigation volumes. The same transplanting geometry was followed. Six ground rows isolated by $1.25-\mathrm{m}$-space were used in each net greenhouse.

The experiment was conducted in 6 classic net greenhouses (area $=9 \mathrm{~m} \times 39 \mathrm{~m}$ ). A split-plot design with three replications (two net greenhouses/replication) was used with irrigation methods as main plots and irrigation levels as subplots (three levels/net greenhouse). The following experimental protocols were adopted:

\section{Factor A: Irrigation method (main plots accommodated in an entire net greenhouse unit):}

a. Conventional Drip irrigation (DI)

b. Subsurface Buried Diffuser (SBD)

Factor B: Irrigation level (subplots, each were comprised of two rows):

a. Level One (Full irrigation) 100\% of crop water consumption

b. Level Two $75 \%$ of crop water consumption

c. Level Three $50 \%$ of crop water consumption

Tomato, Ezebella which is commonly grown in the country, was planted in the experiment. In all net greenhouses, 3-4 weeks old seedlings were transplanted $40 \mathrm{~cm}$ apart in each row and each plant was served with one dripper/ containing diffuser in the case of both irrigation methods. Each net greenhouse had a total of six rows. Fertilizer application besides all Qatari long-practiced agricultural recommendations were followed.

\subsection{Surveying of tomato fungal diseases}

Survey of root rot and wilt disease of tomato plant after plantation(3-6 weeks after transplanting) was done. The percentage of different diseases incidence was recorded. The average percentages of root rot and wilt disease were calculated as the number of infected plants relative to the total number of examined plants. Crop monitoring is the continually on-going surveillance to detect the presence of a disease at the very early stages of development before economic damage has occurred.

\subsubsection{Total Microbial Count from Rhizosheric Soil}

Rhizospheric samples around healthy and diseased plants using $50 \%, 75 \%$, and $100 \%$ of water consumption were collected at flowering growth stage during the year 2016/2017 and 2017/ 2018 under Buried Diffuser Irrigation System (SBD) and Drip Irrigation System (DI). The total bacterial count and the total fungal count was determined using serial dilution method. The plate count technique according to (Allen O.N., 1961) was followed for both total fungal and bacterial counts. The total bacterial and fungal count under both the irrigation method (SBD \& DI) was recorded and calculated.

\subsubsection{Frequency Occurrence of isolated fungi in rhizospheric soil}

Rhizospheric samples around healthy and diseased plants using $50 \%, 75 \%$, and $100 \%$ of water consumption were collected at flowering growth stage during the year 2016/2017 and 2017/ 2018 under Buried Diffuser Irrigation System (SBD) and Drip Irrigation System (DI). The total fungal count was determined using serial dilution method. The plate count technique according to (Allen O.N., 1961) was followed for total fungal counts. The frequency occurrence of different fungi on each dilution was recorded under both irrigation method. Soil-borne fungi associated with the root region of healthy and infected roots of Tomato plants were then isolated following the method developed by(Louw H. A., and Weblely D.W., 1959) for studying the 
microflora of the root region. The isolated fungi were firstly purified using single spore or hyphal tip techniques then identified according to the cultural morphological growth and microscopical characters as described by Gilman (1957), Barnett and Hunter (1972) and Nelson et al., (1983). The frequency occurrence of different fungi in assayed rhizospheric soil samples under both irrigation method was recorded during the year 2016/2017 and 2017/ 2018. Identification of common fungal spp.,was made according to cultural characteristics and morphological characteristics under the microscope.

\subsection{Isolation, purification and identification of the diseases causal fungal pathogens from diseased Tomato}

Samples of the diseased tomato plants were collected under both irrigation method at two growth stages of plant growth, were transferred to the laboratory of Plant Pathology Unit, Department of Agricultural Research, Ministry of Municipality \& Environment, Qatar. Collected root or shoot systems showing diseases symptoms were subjected to isolation trails for pathogenic fungi. Small pieces of infected roots or stem of tomato were surface sterilized using sodium hypochlorite solution (3\%) for 2 minutes and washed with distilled sterilized water several times. Then dried using sterilized filter paper and transferred into Petri-dishes containing potato dextrose agar medium (PDA). Plates were incubated at $25 \pm 2^{\circ} \mathrm{C}$ for $5-7$ days for appearance fungal colonies. Hyphal tips of fungi were picked up and transferred to another PDA plates. Purified fungi were identified based on their microscopic and morphological characters according to Gilman (1957), Barnett and Hunter (1972) and Nelson et al., (1983)

\subsection{Statistical Analysis}

Analyses of variance were carried out using MSTATC. The least significant difference (L.S.D) was employed to test for significant difference between treatments at $\mathrm{P} \leq 0.05$ (Gomez and Gomez,1984).

\section{RESULTS}

\subsection{Disease Incidence and healthy survival in Tomato Cultivation under Buried Diffuser VS. Drip Irrigation Method at Net Greenhouse conditions during 2016/2017 and 2017/2018 winter seasons}

Data presented in Table (1) clearly shows that the Buried Diffuser Irrigation Method has a lower incidence of root rot and wilt disease as compared with Drip Irrigation. In the SBD method at the level of $75 \%$ of water consumption, there was the lowest percentage of root rot and wilt disease $(6.33 \& 1.57)$ respectively in the year 2016 / 2017. This reflected the highest percentage of healthy survival plants of (92.10).

There was an increase in disease incidence under the Drip Irrigation Method at the less survival of healthy tomato plant. The highest percentage of root rot and wilt disease with the DI Method recorded at the level of $100 \%$ of water consumption was $(14.17 \& 4.16)$ respectively and the percentage of healthy survival plants was (81.67). Concerning in the year $2017 / 2018$, the results were at the same frequency as the first season, whereas SBD was found to be better than DI with a slight difference in root rot and wilt disease. Under the Buried Diffuser Irrigation Method at the level $75 \%$ of water consumption, root rot recorded was (8.75) and percentage of healthy survival plants was (88.75) meanwhile under the Drip Irrigation (DI) Method at the level $100 \%$ of water consumption, root rot recorded was (16.25) and healthy survival plants was (79.58). 
Table (1 )Disease Incidence and healthy survival in Tomato Cultivation under Buried Diffuser VS. Drip Irrigation Method at Net Greenhouse conditions during 2016/2017 and 2017/2018 winter seasons

\begin{tabular}{|c|c|c|c|c|c|c|c|}
\hline \multirow{3}{*}{ Irrigation Method } & \multirow{3}{*}{$\begin{array}{l}\text { Irrigation } \\
\text { Level \% }\end{array}$} & \multicolumn{3}{|c|}{$2016 / 2017$} & \multicolumn{3}{|c|}{$2017 / 2018$} \\
\hline & & \multicolumn{2}{|c|}{ Diseases incidence \% } & \multirow[b]{2}{*}{$\begin{array}{c}\text { Healthy } \\
\text { survival \% }\end{array}$} & \multicolumn{2}{|c|}{ Diseases incidence \% } & \multirow[b]{2}{*}{$\begin{array}{l}\text { Healthy } \\
\text { survival \% }\end{array}$} \\
\hline & & Root rot & Wilt & & Root rot & Wilt & \\
\hline \multirow{3}{*}{$\begin{array}{l}\text { Buried Diffuser } \\
\text { Irrigation(SBD) }\end{array}$} & 50 & 9.58 & 3.08 & 87.34 & 12.50 & 1.25 & 86.25 \\
\hline & 75 & 6.33 & 1.57 & 92.10 & 8.75 & 2.50 & 88.75 \\
\hline & 100 & 10.00 & 2.61 & 87.39 & 11.66 & 2.08 & 86.26 \\
\hline \multirow[t]{3}{*}{ Drip Irrigation Method (DI) } & 50 & 13.76 & 1.66 & 84.58 & 10.83 & 3.75 & 85.42 \\
\hline & 75 & 13.16 & 2.08 & 84.76 & 14.16 & 2.50 & 83.34 \\
\hline & 100 & 14.17 & 4.16 & 81.67 & 16.25 & 4.17 & 79.58 \\
\hline \multicolumn{8}{|l|}{ L.S.D at 0.05 for: } \\
\hline A & & 2.47 & 0.70 & ns & 4.57 & 1.46 & 3.17 \\
\hline B & & ns & 0.88 & ns & ns & ns & 2.56 \\
\hline$A \times B$ & & 3.37 & 1.24 & ns & 5.07 & 1.97 & 3.62 \\
\hline
\end{tabular}

\subsubsection{Total Microbial Count from Rhizosheric Soil}

Tables $(2 \mathrm{a} \& 2 \mathrm{~b})$ show the total bacterial and fungal count randomly in rhizosphere around infected and healthy tomato plant under both irrigation methods. The total microbial count was done generally to study the microflora of the soil. Average counts of microorganisms were expressed as CFU per1 gm. of dry soil with their respective dilutions. There were no significant differences in the count of bacteria and fungi in the rhizospheric soil during the year 2016 / 2017 and 2017 / 2018. The fungal and bacterial count was recorded higher in the rhizosphere around infected plant under Drip irrigation method at $100 \%$ of water consumption. Under the SBD Method the total fungal count of rhizosphere around infected tomato plant was $(38 \times 103)$ and $(42 \times 103)$ at the level of $75 \%$ and $100 \%$ of water consumption, respectively, whereas under the DI Method there was an increase in the total fungal count in rhizosphere around infected tomato plant. The recorded count was $(11 \times 104)$ and $(21 \times 104)$ at the level of $75 \%$ and $100 \%$ of water consumption, respectively in the year 2016 / 2017. In the year 2017 / 2018, the total fungal count under SBD and DI irrigation methods were almost the same $(29 \times 103$ and $24 \times 103)$ respectively at $75 \%$ of water consumption and an increase in the fungal count $(7 \times 104$ and $24 \times 103)$ was recorded under DI as compared to SBD respectively at $100 \%$ of water consumption.

The total bacterial count was also recorded higher in the rhizosphere around infected tomato plant under DI at the level of $75 \%$ and $100 \%$ of water consumption as compared to SBD during the year $2016 / 2017$ and 2017 / 2018. 
Table (2a) Total Fungal Count (TFC) on different Irrigation Method

\begin{tabular}{|c|c|c|c|c|c|}
\hline \multirow[b]{3}{*}{$\begin{array}{l}\text { Irrigation } \\
\text { Method }\end{array}$} & \multirow[b]{3}{*}{$\begin{array}{l}\text { Irrigation } \\
\text { Level \% }\end{array}$} & \multicolumn{4}{|c|}{ TOTAL FUNGAL COUNT cfu/gm of soil } \\
\hline & & \multicolumn{2}{|c|}{$2016 / 2017$} & \multicolumn{2}{|c|}{$2017 / 2018$} \\
\hline & & $\begin{array}{l}\text { TFC of rhizosphere } \\
\text { around Healthy } \\
\text { Tomato Plant }\end{array}$ & $\begin{array}{l}\text { TFC of rhizosphere } \\
\text { around Infected } \\
\text { Tomato Plant }\end{array}$ & $\begin{array}{c}\text { TFC of } \\
\text { rhizosphere } \\
\text { around Healthy } \\
\text { Tomato Plant }\end{array}$ & $\begin{array}{l}\text { TFC of rhizosphere } \\
\text { around Infected } \\
\text { Tomato Plant }\end{array}$ \\
\hline \multirow{3}{*}{$\begin{array}{l}\text { Buried Diffuser } \\
\text { Irrigation (SBD) }\end{array}$} & 50 & $18 \times 10^{3}$ & $34 \times 10^{3}$ & $07 \times 10^{3}$ & $22 \times 10^{3}$ \\
\hline & 75 & $23 \times 10^{3}$ & $38 \times 10^{3}$ & $20 \times 10^{3}$ & $29 \times 10^{3}$ \\
\hline & 100 & $29 \times 10^{3}$ & $42 \times 10^{3}$ & $34 \times 10^{3}$ & $24 \times 10^{3}$ \\
\hline \multirow{3}{*}{$\begin{array}{l}\text { Drip irrigation } \\
\text { Method (DI) }\end{array}$} & 50 & $8 \times 10^{3}$ & $17 \times 10^{3}$ & $12 \times 10^{3}$ & $15 \times 10^{3}$ \\
\hline & 75 & $29 \times 10^{3}$ & $11 \times 10^{4}$ & $15 \times 10^{3}$ & $24 \times 10^{3}$ \\
\hline & 100 & $32 \times 10^{3}$ & $21 \times 10^{4}$ & $18 \times 10^{3}$ & $7 \times 10^{4}$ \\
\hline
\end{tabular}

Table (2b) Total Bacterial count (TBC) on different Irrigation Method

\begin{tabular}{|c|c|c|c|c|c|}
\hline \multirow[b]{3}{*}{$\begin{array}{l}\text { Irrigation } \\
\text { Method }\end{array}$} & \multirow[b]{3}{*}{$\begin{array}{l}\text { Irrigation } \\
\text { Level \% }\end{array}$} & \multicolumn{4}{|c|}{ TOTAL BACTERIAL COUNT cfu/gm of soil } \\
\hline & & \multicolumn{2}{|c|}{$2016 / 2017$} & \multicolumn{2}{|c|}{$2017 / 2018$} \\
\hline & & $\begin{array}{c}\text { TBC of rhizosphere } \\
\text { around Healthy } \\
\text { Tomato Plant }\end{array}$ & $\begin{array}{l}\text { TBC of rhizosphere } \\
\text { around } \\
\text { InfectedTomato Plant }\end{array}$ & $\begin{array}{c}\text { TBC of } \\
\text { rhizosphere } \\
\text { around Healthy } \\
\text { Tomato Plant }\end{array}$ & $\begin{array}{c}\text { TBC of rhizosphere } \\
\text { around Infected } \\
\text { Tomato Plant }\end{array}$ \\
\hline \multirow{3}{*}{$\begin{array}{l}\text { Buried Diffuser } \\
\text { Irrigation (SBD) }\end{array}$} & 50 & $88 \times 10^{7}$ & $159 \times 10^{8}$ & $19 \times 10^{7}$ & $32 \times 10^{9}$ \\
\hline & 75 & $42 \times 10^{8}$ & $24 \times 10^{9}$ & $28 \times 10^{7}$ & $54 \times 10^{9}$ \\
\hline & 100 & $66 \times 10^{8}$ & $110 \times 10^{9}$ & $12 \times 10^{8}$ & $85 \times 10^{9}$ \\
\hline \multirow{3}{*}{$\begin{array}{l}\text { Drip irrigation } \\
\text { Method (DI) }\end{array}$} & 50 & $49 \times 10^{8}$ & $39 \times 10^{9}$ & $84 \times 10^{7}$ & $27 \times 10^{9}$ \\
\hline & 75 & $65 \times 10^{8}$ & $97 \times 10^{9}$ & $28 \times 10^{8}$ & $101 \times 10^{9}$ \\
\hline & 100 & $82 \times 10^{8}$ & $169 \times 10^{9}$ & $42 \times 10^{8}$ & $152 \times 10^{9}$ \\
\hline
\end{tabular}


Table (3a) Occurrence of isolated Fungi from Rhizosphere around infected tomato plant under Buried Diffuser and Drip Irrigation method in a Net Green House during 2016-2017

\begin{tabular}{|c|c|c|c|c|c|c|c|c|c|c|c|}
\hline $\begin{array}{l}\text { Irrigation } \\
\text { Method }\end{array}$ & $\begin{array}{c}\text { Irrigation } \\
\text { Level \% }\end{array}$ & $\begin{array}{l}\text { Fusarium } \\
\text { oxysporum }\end{array}$ & $\begin{array}{l}\text { Fusarium } \\
\text { solani }\end{array}$ & $\begin{array}{c}\text { Rhizoctonia } \\
\text { solani }\end{array}$ & $\begin{array}{l}\text { Pythium } \\
\text { spp. }\end{array}$ & $\begin{array}{c}\text { Aspergillus } \\
\text { nidulans }\end{array}$ & $\begin{array}{l}\text { Trichoderma } \\
\text { spp. }\end{array}$ & $\begin{array}{c}\text { Penicillium } \\
\text { spp. }\end{array}$ & $\begin{array}{l}\text { Alternaria } \\
\text { spp. }\end{array}$ & $\begin{array}{l}\text { Ulocladium } \\
\text { spp }\end{array}$ & others \\
\hline \multirow{3}{*}{$\begin{array}{c}\text { Buried } \\
\text { Diffuser } \\
\text { Irrigation }\end{array}$} & 50 & 17.65 & 11.76 & 11.76 & 8.82 & 14.71 & - & 8.82 & 8.82 & 11.76 & 5.88 \\
\hline & 75 & 18.42 & 15.79 & 13.16 & 10.53 & 15.79 & 2.63 & 5.26 & 7.9 & 7.9 & 2.63 \\
\hline & 100 & 21.74 & 17.39 & 15.22 & 10.87 & 15.22 & 2.38 & 4.35 & 6.52 & 4.35 & 2.38 \\
\hline \multirow{3}{*}{$\begin{array}{c}\text { Drip } \\
\text { Irrigation } \\
\text { Method }\end{array}$} & 50 & 23.53 & 17.65 & 11.76 & 11.76 & 11.76 & - & 5.88 & 5.88 & 11.76 & 5.88 \\
\hline & 75 & 27.27 & 18.18 & 9.09 & 18.18 & 9.09 & - & 9.09 & 9.09 & - & - \\
\hline & 100 & 28.18 & 19.09 & 16.36 & 11.81 & 15.9 & - & 3.63 & 1.82 & 1.36 & 1.81 \\
\hline
\end{tabular}

Table (3b) Occurrence of isolated Fungi from Rhizosphere around infected tomato plant under Buried Diffuser and Drip Irrigation method in a Net Green House during 2017-2018

\begin{tabular}{|c|c|c|c|c|c|c|c|c|c|c|c|}
\hline $\begin{array}{l}\text { Irrigation } \\
\text { Method }\end{array}$ & $\begin{array}{c}\text { Irrigation } \\
\text { Level \% }\end{array}$ & $\begin{array}{c}\text { Fusarium } \\
\text { oxysporum }\end{array}$ & $\begin{array}{c}\text { Fusarium } \\
\text { solani }\end{array}$ & $\begin{array}{c}\text { Rhizoctonia } \\
\text { solani }\end{array}$ & $\begin{array}{l}\text { Pythium } \\
\text { spp. }\end{array}$ & $\begin{array}{l}\text { Aspergillus } \\
\text { nidulans }\end{array}$ & $\begin{array}{l}\text { Trichoderma } \\
\text { spp. }\end{array}$ & $\begin{array}{l}\text { Penicillium } \\
\text { spp. }\end{array}$ & $\begin{array}{l}\text { Alternaria } \\
\text { spp. }\end{array}$ & $\begin{array}{l}\text { Ulocladium } \\
\text { spp }\end{array}$ & others \\
\hline \multirow{3}{*}{$\begin{array}{c}\text { Buried } \\
\text { Diffuser } \\
\text { Irrigation }\end{array}$} & 50 & 18.18 & 13.64 & 9.09 & 9.09 & 13.64 & - & 13.64 & 9.09 & 9.09 & 4.55 \\
\hline & 75 & 20.69 & 17.24 & 13.79 & 13.79 & 13.79 & - & 3.45 & 6.9 & 6.9 & 3.45 \\
\hline & 100 & 22.22 & 17.78 & 13.33 & 13.33 & 15.56 & 2.22 & 4.44 & 6.67 & 2.22 & 2.22 \\
\hline \multirow{3}{*}{$\begin{array}{c}\text { Drip } \\
\text { Irrigation } \\
\text { Method }\end{array}$} & 50 & 26.66 & 20 & 13.33 & 13.33 & 6.67 & - & 6.66 & 6.66 & 6.66 & - \\
\hline & 75 & 29.17 & 20.83 & 8.33 & 16.67 & 12.5 & - & 8.33 & - & 4.17 & 4.17 \\
\hline & 100 & 31.43 & 21.43 & 14.29 & 17.14 & 12.86 & - & 1.43 & 1.43 & - & - \\
\hline
\end{tabular}

Table (3c) Occurrence of isolated Fungi from Rhizosphere around healthy tomato plant under Buried Diffuser and Drip Irrigation method in a Net Green House during 2016-2017 


\begin{tabular}{|c|ccccccccccc|}
\hline $\begin{array}{c}\text { Irrigation } \\
\text { Method }\end{array}$ & $\begin{array}{c}\text { Irrigation } \\
\text { Level \% }\end{array}$ & $\begin{array}{c}\text { Fusarium } \\
\text { oxysporum }\end{array}$ & $\begin{array}{c}\text { Fusarium } \\
\text { solani }\end{array}$ & $\begin{array}{c}\text { Rhizoctonia } \\
\text { solani }\end{array}$ & $\begin{array}{c}\text { Pythium } \\
\text { spp. }\end{array}$ & $\begin{array}{c}\text { Aspergillus } \\
\text { nidulans }\end{array}$ & $\begin{array}{c}\text { Trichoderma } \\
\text { spp. }\end{array}$ & $\begin{array}{c}\text { Penicillium } \\
\text { spp. }\end{array}$ & $\begin{array}{c}\text { Alternaria } \\
\text { spp. }\end{array}$ & $\begin{array}{c}\text { Ulocladium } \\
\text { spp }\end{array}$ & $\begin{array}{c}\text { others } \\
\text { suried }\end{array}$ \\
50 & 5.55 & 5.55 & 5.55 & 11.11 & 16.67 & 11.11 & 16.67 & 11.11 & 11.11 & 5.55 \\
$\begin{array}{c}\text { Diffuser } \\
\text { Irrigation }\end{array}$ & 75 & 8.7 & 13.04 & 8.7 & 13.04 & 21.74 & 13.04 & 8.7 & 4.35 & 8.7 & 4.35 \\
& 100 & 10.34 & 13.79 & 10.34 & 10.34 & 17.24 & 10.34 & 3.44 & 6.9 & 10.34 & 3.44 \\
\hline $\begin{array}{c}\text { Drip } \\
\text { Irrigation }\end{array}$ & 50 & 11.11 & 11.11 & 11.11 & - & 11.11 & 22.22 & 11.11 & 11.11 & 11.11 & - \\
Method & 75 & 13.79 & 13.79 & 10.34 & 3.45 & 17.24 & 3.45 & 10.34 & 10.34 & 13.79 & 3.45 \\
& 100 & 15.63 & 15.53 & 12.5 & 12.5 & 21.88 & 3.13 & 9.34 & 16 & 9.34 & 3.13 \\
\hline
\end{tabular}

Table (3d) Occurrence of isolated Fungi from Rhizosphere around healthy tomato plant under Buried Diffuser and Drip Irrigation method in a Net Green House during 2017-2018

\begin{tabular}{|c|c|c|c|c|c|c|c|c|c|c|c|}
\hline $\begin{array}{c}\text { Irrigation } \\
\text { Method }\end{array}$ & $\begin{array}{c}\text { Irrigation } \\
\text { Level \% }\end{array}$ & $\begin{array}{l}\text { Fusarium } \\
\text { oxysporum }\end{array}$ & $\begin{array}{c}\text { Fusarium } \\
\text { solani }\end{array}$ & $\begin{array}{c}\text { Rhizoctonia } \\
\text { solani }\end{array}$ & $\begin{array}{l}\text { Pythium } \\
\text { spp. }\end{array}$ & $\begin{array}{c}\text { Aspergillus } \\
\text { nidulans }\end{array}$ & $\begin{array}{c}\text { Trichoderma } \\
\text { spp. }\end{array}$ & $\begin{array}{c}\text { Penicillium } \\
\text { spp. }\end{array}$ & $\begin{array}{c}\text { Alternaria } \\
\text { spp. }\end{array}$ & $\begin{array}{l}\text { Ulocladium } \\
\text { spp }\end{array}$ & others \\
\hline \multirow{3}{*}{$\begin{array}{c}\text { Buried } \\
\text { Diffuser } \\
\text { Irrigation }\end{array}$} & 50 & - & 14.29 & 14.29 & - & 14.29 & 28.57 & - & 14.29 & - & 14.29 \\
\hline & 75 & 5 & 5 & - & 10 & 15 & 10 & 15 & 15 & 10 & 15 \\
\hline & 100 & 5.88 & 2.94 & 8.83 & 2.94 & 2.06 & 8.83 & 14.71 & 11.76 & 14.7 & 8.83 \\
\hline \multirow{3}{*}{$\begin{array}{c}\text { Drip } \\
\text { Irrigation } \\
\text { Method }\end{array}$} & 50 & 8.33 & 8.33 & 8.33 & 6.67 & 16.67 & 8.33 & 16.67 & 8.33 & 8.33 & - \\
\hline & 75 & 6.67 & 13.33 & - & 6.67 & 20 & 6.67 & 20 & 6.67 & 13.33 & 6.67 \\
\hline & 100 & 11.11 & 5.56 & 11.11 & 5.56 & 22.22 & - & 5.56 & 16.67 & 16.67 & 5.56 \\
\hline
\end{tabular}




\subsubsection{Frequency Occurrence of isolated fungi in rhizospheric soil around healthy and infected tomato plants}

The obtained results in tables ( $3 a, b, c \& d$ ) showed that the frequency occurrence of different fungi in assay rhizospheric soil samples. The root fungal pathogens e.g. Fusarium oxysporum, Fusarium solani, Rhizoctonia solani., Pythium spp; Aspergillus spp, were recorded in high frequency in DI as compared with the SBD. The genus Fusarium represented in highest records followed by the genus Rhizoctonia and Aspergillus spp, respectively at all assayed soil samples. Meanwhile, the pathogens referred to genus Alternaria spp, Penicililum spp, and Ulocladium spp, were represented in a lesser frequency. The frequency occurrence of different fungi e.g. Fusarium oxysporum, Fusarium solani, Rhizoctonia solani, Pythium spp, Aspergillus spp, were recorded high in Drip Irrigation Method with $75 \%$ and $100 \%$ water consumption as compared with $50 \%$ of water consumption. The frequency occurrence of different fungi Pythium spp, Fusarium oxysporum., Fusarium solani,Rhizoctonia solani, Aspergillus spp were comparatively very less in the rhizosphere around healthy plant under SBD method and DI. Trichoderma spp., was isolated from the rhizospheric soil around the healthy tomato plants under both irrigation method and their frequency occurrence was recorded. The results show that the presence of pathogenic fungi causing wilt and root rot are comparatively higher in terms of frequency in the rhizosphere around the unhealthy tomato plant using DI method at $75 \%$ and $100 \%$ of water consumption as compared to SBD method during the year 2016/2017 and 2017/2018

\subsection{Isolation, purification and identification of the diseases causal fungal pathogens from infected Tomato Plant.}

Tomato plants showing root rot and wilt symptoms under SBD and DI Methods were subjected to isolation trails for the purpose of isolation of the causal organisms. The isolated fungi were identified as $F$. oxysporum., Fusarium solani., Rhizoctonia solan, Pythium spp., and Ulocladium spp. The genus Fusarium was found to be represented in highest records followed by the genus Pythium and Rhizoctonia solani under DI as compared to SBD.

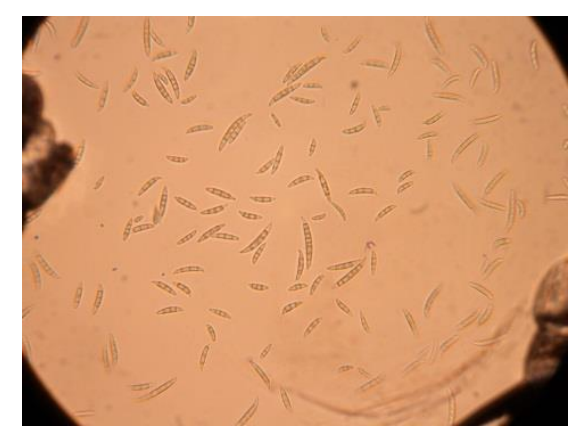

Fusarium solani

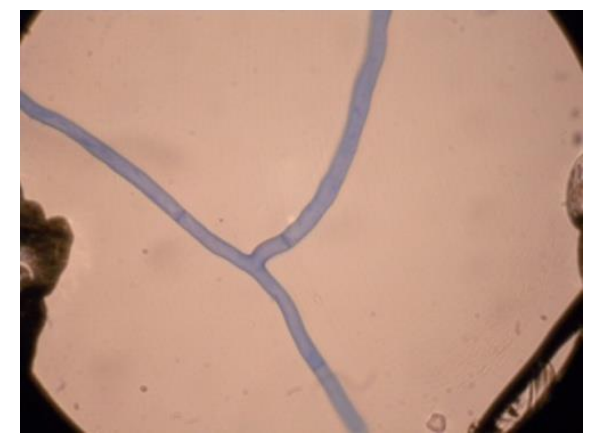

Rhizoctonia solani

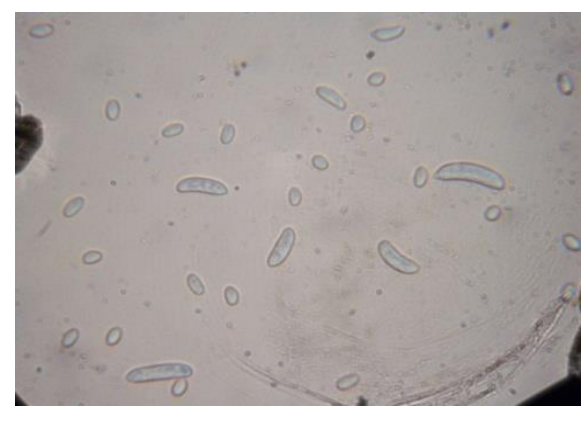

F. oxysporum

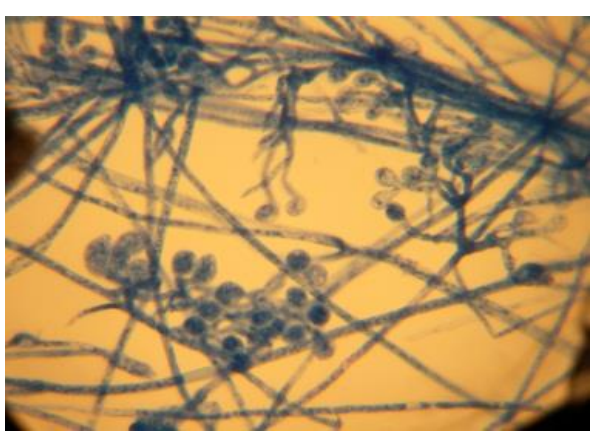

Pythium spp 


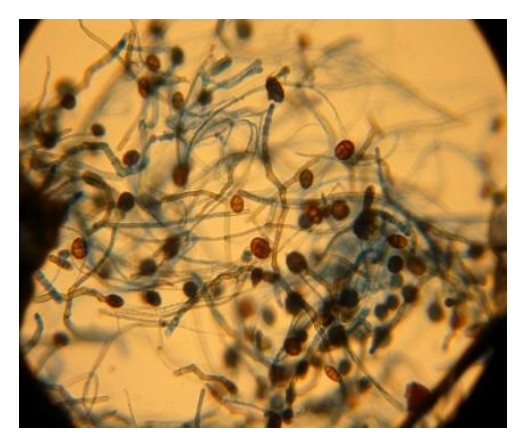

Ulocladium spp

\section{DISCUSSION}

During our study, it has been observed that the disease incidence and severity of wilt and root rot disease of tomato were recorded significantly higher under Conventional Drip Irrigational Method (DI) as compared to Subsurface buried diffuser (SBD) method as observed under the net greenhouse during the year 2016/2018 \& 2017/2018. The healthy plant survival percentage was $92.92 \%$ \& $88.75 \%$ respectively during the year $2016 / 2017$ and $2017 / 2018$ at $75 \%$ of water consumption. As in DI, accumulation of the salt and moisture is more on the surface which in turn can increase the presence of pathogenic fungi in the soil. Salinization and alkalization have substantially changed the property of the soil. The salt-rich soil is characterized by high $\mathrm{pH}$ and large exchangeable sodium percentage (Chi and Wang; 2010). High salinity may also increase the incidence and severity of disease caused by various species of Phytophthora, F. solani, F. oxysporum f.sp, radices lycopersici and Veticillium dahliae and Alternaria solani. (Rietz and Haynes ;2003; Tejada \& Gonzalez;2006) recorded that the excessive amounts of salts accumulated during irrigation can have adverse effects on the chemical and physical properties of the soils and on their biological processes. These effects include mineralization of the carbon and nitrogen and the enzymatic activity, which is crucial for the decomposition of organic matter and liberation of the nutrients necessary for the sustainability of the production (Wong et al., 2008).

In a dry hot climate, the low humidity and soil salinity are the most stressful factors for the soil microbial flora and frequently occur simultaneously. Saline stress can gain importance, especially in agricultural soils where the high salinity may be a result of irrigation. Research has been carried out on naturally saline soils, and the detrimental influence of salinity on the microbial soil communities and their activities reported in the majority of (Rietz and Haynes, 2003; Sardinha et al., 2003). The effect is always more pronounced in the rhizosphere according to the increase in water absorption by the plants due to transpiration. The simple explanation for this is that life in high salt concentrations has a high bioenergetic taxation since the microorganisms need to maintain osmotic equilibrium between the cytoplasm and the surrounding medium, excluding sodium ions from inside the cell. As a result, energy sufficient for osmoadaptation is required (Jiang et al, 2007).

The rhizosphere has long been considered to be the natural reservoir for microorganisms. In our study, the fungal and bacterial count was recorded higher in the rhizosphere around infected plant under Drip irrigation method at $100 \%$ of water consumption. A large array of microbes can inhabit the rhizosphere, and it is widely accepted that members from all microbial groups perform important functions in the rhizosphere (Giri et al.; 2005). Bacteria and fungi are the major types of microorganisms found in soil, play an essential role in nutrients transformation and soil fertility. (Critter et al. ;2002) evaluated both groups of microorganisms in soil samples quantitatively using agar plate counts. Microbial abundance, diversity, and activity largely have implications for the sustainable productivity of agricultural land and production systems. Information on the microbial communities associated with rhizospheres and their complex interrelationship is essential in the selection of sustainable crop rotations and management practices (Lenc et al., 2015; Chen et al.; 2017). information about the occurrence and the organization of fungal organisms in the tomato rhizosphere is currently limited. Furthermore, studies on fungal diversity in desert farming systems remain rare. Considering 
the different ways that can change the farming systems underlying soils and soil microbes, it is essential to understand the fungal diversity and their functions in soils under different management.

The frequency occurrence of different fungi e.g. Pythium spp., Fusarium oxysporum., Fusarium solani, Rhizoctonia solani, Aspergillus spp., were recorded high in Drip Irrigation Method with $75 \%$ and $100 \%$ water consumption as compared with $50 \%$ of water consumption as compared to the buried Diffuser irrigation method. The genus Fusarium represented in highest records. The fungi isolated from root and shoot system of the infected tomato plant under both irrigation method were identified as Pythium sp., Fusarium solani, Fusarium oxysporum, Rhizoctonia solani and Ulocladium spp.,. The genus Fusarium again represented in highest records followed by the genus Pythium and Rhizoctonia solani.

Fusarium oxysporum is major soilborne fungal pathogens of both greenhouse and field grown tomatoes in the warm vegetable growing areas of the world (Rosewich, U.L.; Pettway, R.E et al, 1999). It was reported that Tomato plants are infected by several soilborne fungal pathogens such as Fusarium spp., Rhizoctoniasolani, and Pythium spp., which cause serious diseases as root rots and wilt and finally reduced crop yield and quality (Saad, M.M. 2006, Abdel-Monaim, M.F. 2010). Fusarium wilt of tomato caused by Fusarium oxysporum $f . s p$. Lycopersici and Rhizoctonia solani causing damping off, cankers, root rots, fruit decay, foliage disease causes serious economic loss. Fusarium oxysporum penetrates the roots mainly through wounds and proceeds into and throughout the vascular system, leading to functional collapse, systemic wilting and often the death of the infected plant. Fusarium oxysporum $f$. sp. radicis-lycopersici cause disease on hosts from several plant families, including tomato in the greenhouse (Menzies, J.G.; Koch, C. and Seywerd, F. 1990).

Under SBD irrigation method disease incidence, occurrence of pathogenic fungi causing wilt and root rot was recorded less as compared to DI irrigation Method. One of the most important advantage of SBD is its potentiality. The word potentiality is stressed because irrigation efficiency not only depends on the irrigation system itself but also on its proper design, installation, and management. Only if designed, installed and managed correctly, can SBD be more efficient than any other irrigation system. In SBD, the system only wets a fraction of the soil volume, compared with other systems. This leaves space in the soil to store water from rainfall and may reduce the net irrigation requirements and also keeps the soil surface to stay dry. A dry soil surface means practically no irrigation water is lost due to evaporation and run off. Therefore, an $S$ system can deliver water in an efficient manner as compared to DI. Because of the water conservation efficiency of SBD, it may be a good alternative for areas where the irrigation water is limited. SBD also has environmental benefits, as the water that is applied in excess using drip irrigation method has the potential of creating environmental problems such as nutrient leaching, soil erosion, and pollution of surface and groundwater sources (Amosson,

\section{S.H. et al., 2002; Trooien, T.P. et al 2000).}

\section{CONCLUSION}

In this study of two years, tomato plant irrigated under Drip Irrigation and Buried Irrigation method was studied. Our findings indicated that under Drip irrigation method, the survival of healthy tomato plant was less as compared to Buried Diffuser Irrigation Method. The rhizospheric soil irrigated with Drip Irrigation method showed high fungal and bacterial count. The frequency occurrence of pathogenic fungi causing wilt and root rot was recorded high in the rhizosphere around infected tomato plants under Drip Irrigation Method. All these results lead to the conclusion that Buried diffuser irrigation method could constitute another irrigation method option in the country compared to the Conventional Drip Irrigation with more enhancements and optimization to increase the yield of different vegetable production in Qatar.

The conclusion of this study is based on only 2 years of data regarding the survival of healthy plant and frequency occurrence of pathogenic fungi in rhizospheric soil under Conventional Drip Irrigation method (DI) and the Subsurface Buried Diffuser (SBD) and the results may have some limitation \& so further research is needed in the following years to better understand the interactions among various microbes and how the irrigation method affects the beneficial microorganisms and their contribution to the increase in the survival of healthy plant. 


\section{ACKNOWLEDGEMENT}

The author would like to thank the Department of Agricultural Research of the Ministry of Municipality \& Environment, Qatar for supporting this work.

\section{REFERENCES}

1. Abdel-Monaim, M.F. (2010): Induced systemic resistance in tomato plants against Fusarium wilt disease. Pages 253-ISSN: 2277-3754 ISO 9001:2008 Certified International Journal of Engineering and Innovative Technology (IJEIT) Volume 4, Issue 1, July 2014275 -263. In Proceedings of the 2nd Minia Conference for Agriculture and Environmental Science, 22-25 March, 2010, Minia, Egypt.

2. Allen O.N. (1961): Experiments on Soil Bacteriology. Burgess Publishing Co., Minnesota, USA, 214 pp.

3. Amosson, S.H.m L. New, L. Almas,F. bretz, and T. Marek. (2002): Economics of irrigation systems. Publication B-6113, Texas Cooperative Extension, The Texas A \& M University System, 20 pages.

4. Barnett, H.L. and B.B.Hunter (1972: Illustrated genera of imperfect fungi. Burgess Publishing Company. Minneapolis, Minnesota, $241 \mathrm{pp}$.

5. ChahbaniBellachheb(2012):http://www.solutionsforwater.org/wpcontent/uploads/2012/03/Burieddiffuser-report-February-2012.pdf

6. Chen, Y. L., Xu, T. L., Veresoglou, S. D., Hu, H. W., Hao, Z. P., Y. J. Hu, et al. (2017): Plant diversity represents the prevalent determinant of soil fungal community structure across temperate grasslands in northern China. Soil Biol. Biochem. 110, 12-21. doi: 10.1016/j.soilbio.2017.02.015

7. Chi, C.M., Z.C. Wang, (2010): Characterizing salt-affected soils of Songnen Plain using saturated paste and 1: 5 soil- to - water extraction methods. Arid Land Research Mangement. 24 (1) :1-11.

8. Chowdhury, N.; Marschner, P., R.G. Burns, (2011):Soil microbial activity and community composition: impact of changes in matric and osmotic potential. Siol Biology and Biochemistry, Vol. 43, No 6, (June, 2011), pp. 1229-1236, ISSN: 0038-0717.

9. Critter S.A.M.., Freitass S.S., Airoldi C.(2002): Comparison between microorganism counting and a calorimetric method applied to tropical; soil. Thermochim. Acta, 394 : 133-144.

10. Elisabeth Francisconi Fay (2016): Effect of Salinity on Soil Microorganisms. Brazilian Agricultural Research Center.

11. Gilman, J.C. (1957): A manual of soil fungi. lowa State University Press, Ames, lowa, U.S.A. 450pp.

12. Giri B, Giang PH, Kumari R, Prasad R, A. Varma (2005): Microbial diversity in soil. In: Buscot F, Varma S (eds). Microorganisms in soil: roles in genesis and functions. Springer- Verlag, Heidelberg, pp 19-55.

13. Gomez \& Gomez (1984): Statistical Procedures for Agricultural Research. A. Lviley-Interscience Publication, New York, p. 678.

14. Jiang, H.; Dong, H.; Yu, B.; Liu, X.; Li, Y.; Ji, S. \& C.L. Zhang (2007): Microbial response tosalinity change in Lake Chaka, a hypersaline lake on Tibetan plateau. Environmental Microbiology, Vol. 9, No 10, (July, 2007), pp. 2603-2621, ISSN: 1462-2920. 
15. Jiang, Y.M., Cheng, C.R., Xu, Z.H., Y.Q. Liu, (2012:Effects of single and mixed species forest ecosystems on diversity and function of soil microbial community in subtropical China. Journal of Soils and Sediments. 12, 228-240.

16. Juniper, S., L.K. Abbott (2006): Soil salinity delays germination and limits growth of hyphae from propagules of arbuscular mycorrhizal fungi. Mycorrhiza, Vol. 16, No 5, (July, 2006), pp. 371-379, ISSN: 14321890.

17. Kirda, C., Topcu, S., Kaman, H., Ulger, A.C., Yazici, A., Cetin, M M.R. Derici (2005): Grain yield response and $\mathrm{N}$ - fertilizer recovery of maize under DI field Crop Res. 93, 132-141.

18. Lenc, L., Kwa'sna, H., Sadowski, C., and Grabowski, A. (2015): Microbiota in wheat roots, rhizosphere and soil in crops grown in organic and other production systems. J. Phytopathol. 163, 245-263. doi: 10.1111/jph.12313.

19. Louw H.A, D.W. .; Weblely (1959): The bacteriology of root region of cat plant grown under controlled pot culture conditions. J. Appl. Bacteriol., 22: 216-226.

20. Menzies, J.G.; Koch, C. and F. Seywerd (1990): Addition to host range of Fusariumoxysporumf.sp. Radicis-lycopersici. Plant Dis., 74: 569-572.

21. Nelson, P.E.; Toussoun, T.A. and Marasan, W.F.O. (1983): Fusarium spp. An illustrated manual for identification. The Pennsylvania Univ. Press, press, park. 218 pp.

22. Rietz, D.N., R.J. Haynes (2003): Effects of irrigation induced salinity and sodicity on soil microbial activity. Soil Biology \& Biochemistry, Vol. 35, No 6, (June, 2003), pp. 845-854, ISSN 0038-0717.

23. Rosewich, U.L.; Pettway, R.E.; Katan, T. and H.C. Kistler (1999): Population genetic analysis 128 corroborates dispersal of Fusariumoxysporum f. sp. radicis-lycopersici from Florida to Europe. Phytopathology, 89: 623-630.

24. Saad, M.M. (2006): Destruction of Rhizoctoniasolani and Phytophthoracapsici causing tomato root-rot by Pseudomonas fluorescens lytic enzymes. Res. J. Agric. Biol. Sci., 2: 274-281

25. Sardinha, M.; Muller, T.; Schmeisky, H. \&Joergensen, R.G. (2003): Microbial performance in soils along a salinity gradient under acidic conditions. Applied Soil Ecology, Vol. 23, No 3, (July, 2003), pp. 237-244, ISSN: 0929-1393.

26. Tejada, M.; Garcia, C.; Gonzalez, J.L. \& Hernandez, M.T. (2006): Use of organic amendment as a strategy for saline soil remediation: Influence on the physical, chemical and biological properties of soil. Soil Biology \& Biochemistry, Vol. 38, No 6, (June, 2006), pp. 1413-1421, ISSN 0038-0717.

27. Trooien, T.P., F.R. Lamm, L.R. Stone, M. Alam, D.H. rogers, G.A. Clark, and A.J. Schlegel (2000): Using subsurface drip irrigation with livestock wastewater. Proceedings of the 4th decennial symposium ASAE, Phoenix, 379-384.

28. Veena DR, Priya H R, Raheesa M Khatib, and DivyaJoythi (2014): Soilborne Diseases in Crop Plants and Their Management, Journal of Agriculture and Allied Sciences.

29. Wang, M.C., Liu, Y.H., Wang, Q., Gong, M., Hua,X.M., Pang, Y.J., Hu, S.J., Y.H. Yang (2008): Impacts of methamidophos on the biochemical, catabolic, and genetic characteristics of soil microbialcommunities. Soil Biology and Biochemistry. 40,778-788. 
30. Wang, Y., Zang, Y., Na, Y., Z. Hong Tao (2009): Effect of control lower limit of subsurface irrigation on phosphorus distribution in soil profile of protected land, Trans. Chin. Soc. Agric. Eng. 25, 66-70.

31. Wichern, J.; Wichern, F. \& R.G. Joergensen (2006): Impact of salinity on soil microbial communities and the decomposition of maize in acidic soils. Geoderma, Vol. 137, No 1-2, (December, 2006), pp. 100-108, ISSN: 0016-7061.

32. Wong, V.N.L; Dalal, R.C. \& Greene, R. S. B. (2008): Salinity and sodicity effects on respiration and microbial biomass of soil. Biology and Fertility of Soils, Vol. 44, No 7, (August, 2008), pp. 943-953, ISSN:01782762

\section{Author's Biography with Photos}

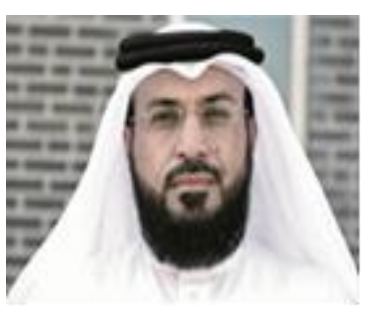

Mr. Masoud J. M. Al-Marri was born in 01/12/1970. He received his B.Sc. in Chemistry in 1990 - 1995 from University of Qatar and M.Sc. in Environmental Engineering Sciences in 1999 - 2001 from University of Florida, USA. At present he is pursuing his Ph.D. in Agricultural \& Environmental Sciences under the University of Sousse, Tunisia (Final Year). Mr. Masoud work experience has included: 1997 - 1999 Environmental Researcher at Environmental Studies Section, The Supreme Council for the Environment \& Natural Reserves, Doha, Qatar; 2002 - 2005 Director, Central Environmental Laboratory, The Supreme Council for the Environment \& Natural Reserves Doha, Qatar; 2007 2009 General Manager, National Environmental Services \& Technologies Doha, Qatar; 2009 - 2012 Director, Biotechnology Center, Ministry of Environment, Doha, Qatar; 2012 - 2014 Technical Advisor, Food Security, Ministry of Environment, Doha, Qatar; 2014 - 2018 Director, Agricultural Research Department, Ministry of Municipality \& Environment, Doha, Qatar; At present Mr. Masoud Al-Marri is an Executive Secretary, Food Security Committee ,Ministry of Municipality \& Environment, Doha, Qatar.

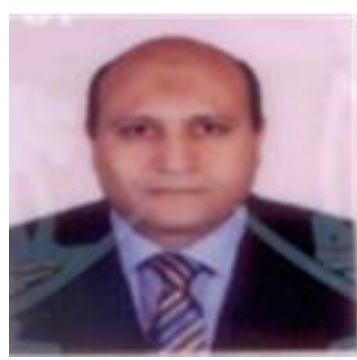

Dr. Mohamed Mahmoud Mazen was born in March 5, 1965. He received his B. .Sc. Agricultural Science (Plant Pathology) in Plant Pathology Department, Faculty of Agricultural, Assuit University (1986) and M.Sc. in Agricultural Science (Plant Pathology), Faculty of Agriculture, Cairo University (1995). Mr. Mohamed Mahmoud Mazen did his Ph.D. Agricultural Science (Plant Pathology). Faculty of Agriculture, Suez Canal University, Egypt (2004). His Thesis Title was : "Resistance induction against diseases of faba bean crop". Dr. Mohamed Mahmoud Mazen work experience has included: Assistant Research, Mayo/1990 - November /1995,Plant Pathology Research Institute, Agricultural Research Center, Giza, EGYPT; Research Assistant, November 1992 November/1999, King Saud University, College of sciences; Researcher, November/1999 - July /2004, Plant Pathology Research Institute, Agricultural Research Center, Giza, EGYPT; Senior Researcher, 2004-2011- Plant Pathology Research Institute, Agricultural Research Center, Giza, EGYPT. Presently working as Plant Pathology Expert; Department of Agricultural Department of Agricultural Research ,Ministry of Municipality \& Environment,Doha, Qatar.

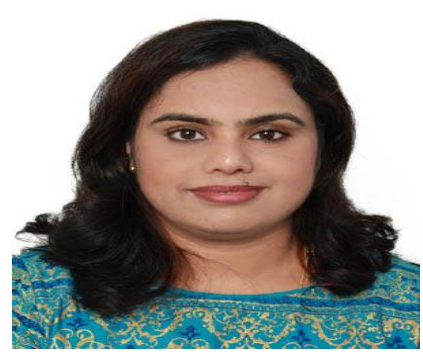

Mrs. Sheeja Thomas was born in March 13 1983. She did her B.Sc Microbiology from R.V.S .College of Arts And Science, Tamil Nadu, India in August 2004 and MSc. in Microbiology from Thanthai Hans Roever College of Arts And Science, Tamil Nadu, India in August 2006. She did her Post Graduate Diploma in Bio Informatics from Thanthai Hans Roever. College of Arts and Science,Tamil Nadu, India in August 2005. Her work experience included: Microbiologist in Genom Biotech Private Limited, Nasik, India from May 2006 to July 2007; Microbiologist in Quality Control Dept in Cipla Limited, Kurkumbh, Pune, India unit from July 2007 to April 2010. At present from 2012 working as Biological researcher in Agricultutral Research Department, Ministry of Municipality and Environment ,Doha, Qatar. 